\title{
Europe (2020)
}

\author{
Federico Casolari*
}

2020 was not an ordinary year in terms of disaster management. The outbreak of the COVID-19 pandemic across the world led to an extraordinary response at every level. In this Section, the reaction elaborated at the European level is taken into consideration. However, the purpose of this Section is neither to provide a comprehensive analysis of all legal tools elaborated in Europe to face the pandemic nor to review, synthetise or analyse the reactions to those tools from different stakeholders and interest groups. Instead, it intends carrying out a legal reflection on the most relevant trends emerging from the response the European Union (EU) has elaborated in this respect. Two main reasons justify such a choice.

First, it has been argued that the EU is the regional international organisation with the most elaborated toolkit in the field of disaster management. ${ }^{1}$ From this perspective, it is not surprising that the number of EU measures taken during the pandemic is particularly remarkable. A global assessment of their effectiveness and distinctive features is thus particularly apt.

Secondly, it cannot be underestimated the impact such measures have produced on the 'constitutional legal framework' of the EU as a regional organisation - that legal framework being understood as a 'structured network of principles, rules and mutually interdependent legal relations binding the EU and its Member States reciprocally and binding its Member States to each other.' ${ }^{2}$ As stressed by some commentators, '[t] he pandemic has reopened old fault lines and amplified problematic trends in the Union, from economic disparities to diverging attitudes to the rule of law. Questions about cooperation, solidarity, trust, values, and thus about the fundamentals of integration and

\footnotetext{
* Associate Professor of EU Law, Alma Mater Studiorum - University of Bologna.

** This survey is realised within the framework of the Research Project of National Relevance 'International legal obligations related to Prevention, Preparedness, Response and Recovery from CBRN events and status of their implementation in Italy - CBRN in Italy', funded by the Italian Ministry of the University (ref. 20175M8L32).

1 Marco Gestri, EU Disaster Response Law: Principles and Instruments, in Andrea de Guttry et al. (eds.), International Disaster Law (т.м.С. Asser Press 2012), 105.

2 Case C-284/16 Achmea ECLI:EU:C:2018:158, para 33.
} 
membership, are on the table. ${ }^{3}$ It is thus opportune to also consider that "constitutional" dimension.

Due to space constraints, it is not possible to give a comprehensive survey of measures adopted at the EU level; the analysis will be thus carried out by stressing the main general trends flowing from the EU's response. ${ }^{4}$ In this respect, the remainder of this Section has been divided into four parts. Part 1 provides a summary of the impact generated by the measures adopted at the EU level on the allocation of competences among the Union and its Member States, the latter representing a crucial element of every legal discourse on the Union. In the light of that analysis, Part 2 describes the roles and responsibilities assumed by different $\mathrm{EU}$ institutions in dealing with the crisis. In doing so, it assesses the impact of the EU's response on the institutional framework (and balance) of the Union. Part 3 provides a general reflection on the main features characterising the instruments adopted by the Union in that context, with a particular emphasis on the recurrent use of soft-law acts. Finally, Part 4 zooms in on the major developments that occurred in 2020 regarding the Union Civil Protection Mechanism (UCPM), due to its major relevance in the EU disaster law discourse.

\section{The Impact of the EU's Response to the COVID-19 Crisis on the Allocation of Competences between the Union and its Member States}

'In the last six months, our health systems and workers have produced miracles. Every country has worked to do its best for its citizens. And Europe has done more together than ever before. When Member States closed borders, we created green lanes for goods. When more than 6oo,ooo European citizens were stranded all over the world, the EU brought them home. When some countries introduced export bans for critical medical goods, we stopped that and ensured that critical medical supply could go where it was needed. We worked

3 Editorial Comments, 'Disease and recovery in (COVID-afflicted) Europe', (2020) 57 Common Market Law Review, 619.

4 For a general overview of the EU's response, see Giacomo Di Federico, 'Stuck in the middle with you ... wondering what it is I should do. Some considerations on EU's response to COVID-19' (2020) Eurojus.it, 6o; see also the Special Focus on Covid-19 and the EU, edited by Charlotte Beaucillon, which is hosted on the European Forum of European Papers. A timeline of the EU action is available at: <https://ec.europa.eu/info/live-work-travel-eu/ coronavirus-response/timeline-eu-action_en>, last accessed (as any subsequent URL) on 15 August 2021. 
with European industry to increase the production of masks, gloves, tests and ventilators. Our Civil Protection Mechanism ensured that doctors from Romania could treat patients in Italy or that Latvia could send masks to its Baltic neighbours. And we achieved this without having full competences. ${ }^{5}$ These words, solemnly pronounced by the President of the European Commission Ursula von der Leyen - in front of the plenary of the European Parliament on the occasion of the 2020 State of the Union, ${ }^{6}$ expresses better than anything else the impact of the COVID-19 emergency on the allocation of competences between the Union and Member States.

No doubt, the Union has made significant recourse to pre-existing instruments pertaining to the so-called EU disaster law to face the CovID-19 crisis. In particular, as also mentioned by the President of the European Commission in her speech, the UCPM has been activated to: i) deploy assistance to States in need (also through the mobilisation of RescEU medical reserves ${ }^{7}$ ) and ii) organise a coordinated repatriation of EU citizens. ${ }^{8}$ A relevant role has also been played by the Decision No. 1082/2013 on serious cross-border threats to support cooperation and coordination between the Member States to prevent and fight against the spread of the pandemic.

Likewise, pre-existing powers for emergency support foreseen in the context of the economic, monetary and financial policies of the Union have been triggered. ${ }^{9}$ Among the most relevant expressions of this course of action one may include: the decision to activate the so-called 'general escape clause' of the Stability and Growth Pact, ${ }^{10}$ the adoption of a temporary framework for State aid measures to support the Member States' economy, ${ }^{11}$ the decision by

$5 \quad$ Emphasis added.

6 European Commission, State of the Union Address 2020, 16 September 2020, <https:// ec.europa.eu/info/strategy/strategic-planning/state-union-addresses/state-union -2020_en>.

7 See infra, part. 4 .

8 European Commission, 'Coronavirus: Unique EU consular operation brought home over 500,ooo EU citizens from abroad', Daily News, 17 April 2020, <https://ec.europa.eu/ commission/presscorner/detail/en/mex_2o_686>.

9 For a general overview see Jonatan Echebarria Fernández, 'A critical analysis on the European Union's measures to overcome the economic impact of the COVID-19 pandemic', (2020) 5 European Papers. European Forum, 1399.

10 European Commission, Communication on the activation of the general escape clause of the Stability and Growth Pact, doc. $\operatorname{COM}(2020) 123$ final, 20 March 2020. The clause allows Member States to depart temporarily from the adjustment path towards budgetary objectives in periods of severe economic downturn.

11 European Commission, Temporary framework for State aid measures to support the economy in the current CoviD-19 outbreak, doc. C(2020) 1863 final, 19 March 2020. See also Alessandro Rosanò, Adapting to change: COVID-19 as a factor shaping EU state aid 
the European Central Bank (ЕСВ) to adopt a non-standard monetary policy to counter serious risks to the monetary policy transmission mechanism and the outlook for the Euro area posed by the COVID-19 outbreak, ${ }^{12}$ the adoption of a European instrument for temporary support to mitigate unemployment risks in an emergency (SURE) following the COVID-19 outbreak, ${ }^{13}$ and, last but not least, the launch of the Next Generation EU Recovery Package. ${ }^{14}$

Significantly, a great number of measures have been adopted by EU institutions relying on competences (such as those related to civil protection cooperation and health policy) which gives the Union a "soft" power, preventing the organisation from adopting harmonising measures. Those competences have been exercised in a "creative" way by EU institutions, allowing the Union to effectively support Member States. The massive recourse to RescEU capabilities is particularly illustrative of such a trend. ${ }^{15}$ Moreover, even in contexts where the Union enjoys an exclusive competence (e.g., monetary policy) its reaction to the COVID-19 pandemic has assumed an unconventional character. The ECB's pandemic emergency purchase programme (PEPP) established to face the threats of CoviD-19 replicates in this respect the innovative scheme adopted by the Есв during the economic and financial crisis, which led the institution to the launch of the public sector purchase programme (PSPP). ${ }^{16}$

More generally, as made clear by Ursula von der Leyen in her address to the European Parliament, the red thread connecting all measures adopted at

law, (2020) 5 European Papers. European Forum, 621; Andrea Biondi and Oana Stefan, EU Health Union and State aid policy: with great(er) power comes great responsibility, (2020) 11 European Journal of Risk Regulation, 894.

12 Decision (EU) 2020/440 of the European Central Bank of 24 March 2020 on a temporary pandemic emergency purchase programme, oJ L91, 25 March 202O, 1.

13 Council Regulation (EU) 2020/672 of 19 May 2020, OJ L159, 20 May 2020, 1.

14 Council Regulation (EU) 2020/2094 of 14 December 2020 establishing a European Union Recovery Instrument to support the recovery in the aftermath of the CovID-19 crisis, OJ L433I, 22 December 2020, 23.

15 As already maintained by the present author, the introduction of the RescEU capacities in the EU civil protection toolkit has significantly reshaped the functioning of the latter, casting doubt on the full consistency of the reform with the 'soft' nature of the EU competence in that domain: Federico Casolari, Europe (2018), (2019) 1 Yearbook of International Disaster Law, 346, 349. See also infra, Part 4.

16 This is why the decision adopted by the Second Senate of the German Federal Constitutional Court on 5 May 2020 (2 BvR 859/15, 2 BvR 1651/15, 2 BvR 2006/15, 2 BvR 980/16), declaring the ECB's decision to launch the PSPP manifestly inconsistent with the principle of proportionality has been considered as a potential threat to the implementation of the PEPP. See on this Annamaria Viterbo, The PSPP judgment of the German Federal Constitutional Court: throwing sand in the wheels of the European Central Bank, (2020) 5 European Papers. European Forum, 671. 
the EU level to face the pandemic seems to be represented by a flexible interpretation of the principle of conferral, as it is understood in EU primary law. ${ }^{17}$ This gives the Union the possibility to assume a rather robust role in responding to the emergency even in absence of a specific mandate enshrined in the EU Treaties. Concretely, that trend has led the Union to assume coordinating powers vis-à-vis the emergency. ${ }^{18}$

Two further examples may contribute to shed more light on such a reconceptualisation of the principle of conferral.

The first example is related to the action put in place to manage the circulation of goods and persons among the EU Member States during the pandemic. As it is well-known, the freedoms of movement of goods and persons represent two major pillars of the EU Single Market, which in turn constitutes a veritable cornerstone of the European integration process. Yet, EU law recognises the Member States' prerogative to introduce limitations and restrictions to those freedoms to safeguard, inter alia, public security and public health (Articles 36 and 45 TFEU). ${ }^{19}$ However, while in past emergencies Member States mainly exercised such prerogatives unilaterally, significantly undermining the functioning of the Single Market, ${ }^{20}$ during the Covid-19 emergency, after some initial hesitations, ${ }^{21}$ the decision was taken to introduce coordinating

17 Pursuant to Article 5, para. 2, TEU, '[u]nder the principle of conferral, the Union shall act only within the limits of the competences conferred upon it by the Member States in the Treaties to attain the objective set out therein. Competences not conferred upon the Union in the Treaties remain with the Member States'. The principle is repeatedly mentioned in the introductory articles of the Treaty on the European Union, representing thus a sort of mantra that illustrates the obsession of Member States to limit the EU's mandate.

18 Alberto Alemanno, 'The European Response to COVID-19: From Regulatory Emulation to Regulatory Coordination', (2020) 11 European Journal of Risk Regulation, 307.

19 Panos Koutrakos et al. (eds.), Exceptions from EU free movement law. Derogation, justification and proportionality (Hart Publishing, 2016).

20 This was particularly evident in the context of the so-called 'refugee crisis' (2015) where the great majority of Member States decided unilaterally to (temporarily) reintroduce border controls to face the unexpected migration flows, leading to a de facto suspension of the free movement of persons within the Schengen area. Cfr. Elspeth Guild, Evelien Brouwer, Kees Groenendijk and Sergio Carrera, What is happening to the Schengen borders?, CEPS Paper in Liberty and Security in Europe, No. 86, December 2015, <https:// www.ceps.eu/wp-content/uploads/2015/12/No\%2086\%2oSchengenland_o.pdf > .

21 At the initial stage of the CoviD-19 spread in Europe several EU countries introduced restrictions to the export of face masks: see OECD, The face mask global value chain the CoviD-19 outbreak: Evidence and policy lessons (4 May 2020) <https://www.oecd.org/ coronavirus/policy-responses/the-face-mask-global-value-chain-in-the-covid-19 -outbreak-evidence-and-policy-lessons-a4df866d/>. Limitations were also introduced to the free movement of persons in the Schengen Area: European Commission, Member 
mechanisms to (try to) minimise the impact of Member States' unilateral decisions on other Member States and the EU as a whole. In particular, Member States were asked to notify each other and the Commission in due time before unilaterally introducing measures restricting (and, at later stage, reintroducing) the free movement of goods and persons. ${ }^{22}$ Moreover, the European Commission assumed an initiative to make sure that border management measures adopted by Member States to protect health did not affect the movement of goods and essential services - the so-called 'Green Lanes' initiative, identifying border crossings open to all freight vehicles carrying goods where any checks or health screenings should take no more than 15 minutes. ${ }^{23}$

The same rationale - that is, the need to consider the strict intertwinement among the Member States within the EU Single Market and their mutual interdependence ${ }^{24}$ - is behind the decision to establish an EU Strategy for COVID-19 vaccines. Indeed, as stated by the European Commission in that Strategy, '[j]oint action at EU level is the surest, quickest and most efficient way' of giving all $27 \mathrm{EU}$ Member States access to a vaccine as early as possible. ${ }^{25}$ Even if Member States remain responsible for their health policies (including the vaccination policies), the common EU approach introduced by the Strategy established a coordinating mechanism in the form of advance purchase agreements negotiated and concluded by the European Commission on behalf of Member States with pharmaceutical companies. Also importantly, contracts were funded by the EU through the Emergency Support Instrument, a facility

States' notifications of the temporary reintroduction of border control at internal borders pursuant to Article 25 and 28 et seq. of the Schengen Borders Code, <https://ec.europa .eu/home-affairs/sites/default/files/what-we-do/policies/borders-and-visas/schengen/ reintroduction-border-control/docs/ms_notifications_-_reintroduction_of_border_con trol.pdf>.

European Commission and European Council, Joint European Roadmap towards lifting covid-19 containment measures, 15 April 2020, <https://ec.europa.eu/info/sites/default/ files/communication_-_a_european_roadmap_to_lifting_coronavirus_containment _measures_o.pdf $>$. See also Stefano Montaldo, 'The COVID-19 emergency and the reintroduction of internal border controls in the Schengen area: never let a serious crisis go to waste' (2020) 5 European Papers. European Forum, 523.

23 European Commission, Communication on the implementation of the Green Lanes under the Guidelines for border management measures to protect health and ensure the availability of goods and essential services, doc. C(2020) 1897 final, 23 March 2020; European Commission, Communication upgrading the transport Green Lanes to keep the economy going during the COVID-19 pandemic resurgence, doc. Сом(2O20)685 final 28 October 2020 .

24 See also Alessio M. Pacces, Maria Weimer, From diversity to coordination: a European approach to COVID-19, (2020) 11 European Journal of Risk Regulation, 283.

25 European Commission, doc. СОМ(2020) 245 final, 17 June 2020. 
based on art. 122, para. 1, TFEU - i.e., a legal basis allowing the Council to adopt 'the measures appropriate to economic situation, in particular if severe difficulties arise in the supply of certain products, notably in the area of energy' -, which was originally created to give financial assistance to Greece during the refugee crisis. ${ }^{26}$

In sum, thanks to the acquiescence of Member States, the Union has had the opportunity to fill some gaps in its mandate by introducing new coordination tools which have in turn extended and strengthened pre-existing emergency instruments. Such a reconceptualisation of the principle of conferral, which of course does not cancel Member States' prerogatives in the context of public security and public health, was deemed necessary due to the need to preserve some of the most relevant achievements of the EU integration process, starting from the Single Market. ${ }^{27}$

\section{3} Towards a New Institutional Balance?

The reconceptualisation of the principle of conferral emerging from the EU's response to the COVID-19 emergency has inevitably modified the interaction among the EU institutions. In particular, the major innovation seems to be represented by a stronger interplay between the European Council and the European Commission. This is not the first time that these two political institutions, representing the two "souls" of the European Union - the European Council constituting the expression of the intergovernmental dimension of the Union, ${ }^{28}$ and the European Commission reflecting its supranational

26 Council Regulation (EU) 2020/521 of 14 April 2020 activating the emergency support under Regulation (EU) 2016/369, and amending its provisions taking into account the COVID-19 outbreak, OJ L117, 15 April 2020, 3.

27 Cfr. also Federico Casolari, Leale cooperazione tra Stati membri e Unione europea (Editoriale Scientifica, 202O), 192-202. In some respect, this trend represents a larger manifestation of the so-called 'framing of powers doctrine' elaborated by the Court of Justice of the European Union, according to which the exercise of Member States' prerogatives (or their retained powers) shall in any case be carried out having regard to EU law to prevent possible consequences on the fulfillment of EU objectives. Cfr. Loïc Azoulai, 'The 'retained powers' formula in the case law of the European Court of Justice: EU law as total law?' (2011) 4 European Journal of Legal Studies, 192.

28 Pursuant to Article 15 TEU, the European Council gathers the Heads of State or Government of the Member States and defines the EU's political strategy, giving thus expression to the prerogative of Member States as 'Masters of the Treaties'. 
nature 29 -, play together. However, while in the past commentators stressed (and criticised) the tendency of the European Commission to act as a sort of secretariat of the European Council, ${ }^{30}$ being de facto subordinated to the latter, the machinery put in place to respond to the CoviD-19 emergency has revealed a new scenario, where the two institutions seem to operate in closer synergy, with the European Commission assuming coordinating tasks over the Member States.

Particularly illustrative of such a trend is the Joint European Roadmap towards lifting COVID-19 containment measures, ${ }^{31}$ which was adopted in April 2020 by the President of the European Council and the President of the European Commission upon request of the Members of the European Council. The Roadmap sets out recommendations to Member States, with the goal of preserving public health while gradually lifting containment measures to restart community life and economy. In doing so, it gives voice to the Member States' prerogatives without underestimating the need to coordinate their action throughout the initiatives put in place by the European Commission. Needless to say, it is too soon to assess the impact of those developments on the institutional balance described in the EU Treaties. However, one cannot ignore that such interplay risks further marginalising the role of the European Parliament (i.e., the political institution directly representing EU citizens), ${ }^{32}$ casting shadows on the transparency and legitimacy of the instruments adopted to face the crisis.

\section{$4 \quad$ Responding "Softly" ... The Increasing Recourse to Soft Law in the Response to the COVID-19 Emergency}

The changes described in the previous two Parts - that is, the circumstance that the Union has acted in several cases without a clear mandate conferred upon it by the Treaties and the fact that the European Commission has assumed new coordinating powers (in strict cooperation with the European Council) - are not without consequences on the toolkit put in place to face

29 According to Article $17 \mathrm{TEU}$, the members of the Commission shall be chosen on the ground of their general competence and European commitment from persons whose independence is beyond doubt. They promote the general interest of the Union. Federico Casolari (eds.), The EU after Lisbon. Amending or coping with the existing Treaties? (Springer 2014) 1, 5 .

31 Supra (n 22).

32 Article 14, para 2, TEU. 
the pandemic. Indeed, these changes have led to a proliferation of soft-law instruments, primarily adopted by the Commission, to set out guidelines and recommendations to Member States. ${ }^{33}$ Such trend is clearly visible in different domains of cooperation: borders management, ${ }^{34}$ health cooperation, ${ }^{35}$ data protection and tracing tools, ${ }^{36}$ etc.

It is important to note in this respect that the recourse to soft and informal instruments in emergency scenarios has become a common place at the EU level. A similar trend emerged in the Union's reaction to the economic and financial crises and the refugee crisis. ${ }^{37}$ Also importantly, that trend does not represent a peculiar feature of EU law: a large recourse to soft-law instruments to face the CoviD-19 pandemic is also documented at the international and

33 According to the EU Court of Justice, "[r] ecommendations, which [...] are not binding, are generally adopted by the institutions of the Community [now Union] when they do not have the power under the Treaty to adopt binding measures or when they consider that it is not appropriate to adopt more mandatory rules.' Case C-322/88, Grimaldi ECLI:EU:C:1989:646, para. 13; emphasis added.

34 European Commission, CoviD-19: temporary restrictions on non-essential travel to the EU, doc. $\operatorname{COM}(2020) 115$ final, 16 March 2020; European Commission, Guidelines for border management measures to protect health and ensure the availability of goods, doc. $\mathrm{C}(2020) 1753$ final, 16 March 2020; European Commission, Guidelines concerning the exercise of the free movement of workers during CoviD-19 outbreak, oJ Cl102, 30 March 2020, 12; Council Recommendation (EU) 2020/912 of 30 June 2020 on the temporary restriction on non-essential travel into the EU and the possible lifting of such restriction, oJ L2O8I, 1 July 202O, 1; Council Recommendation (EU) 2020/1475 of 13 October 2020 on a coordinated approach to the restriction of free movement in response to the COVID-19 pandemic, OJ L337, 14 October 2020, 3; Commission Recommendation on a coordinated approach to travel and transport in response to the SARS-CoV-2 variant observed in the United Kingdom, doc. C(2020)9607 final, 22 December 2020.

35 European Commission, Guidelines on EU emergency assistance in cross-border cooperation in healthcare related to CoviD-19 crisis, doc. Сом(2020)2153 final, 3 April 2020; European Commission, Guidelines on Covid-19 in vitro diagnostic tests and their performance, OJ Cl122, 15 April 2020, 1; European Commission, EU Strategy for COVID-19 vaccines, cit. supra n. 25 .

36 Commission Recommendation (EU) 2020/518 of 8 April 2020 on a common Union toolbox for the use of technology and data to combat and exit from the coviD-19 crisis, in particular concerning mobile applications and the use of anonymized mobility data, OJ L114, 14 April 2020, 7; European Commission, Guidance on Apps supporting the fight against CoviD-19 pandemic in relation to data protection, OJ C124I, 17 April 2020, 1.

37 Jacopo Alberti, 'Challenging the evolution of the EMU: the justiciability of soft law measures enacted by the ECB against the financial crisis before the European courts' (2018) 37 Yearbook of European Law, 626; Federico Casolari, 'The unbearable 'lightness' of soft law: on the European Union's recourse to informal instruments in. the fight against irregular immigration', in Francesca Ippolito et al. (eds) Bilateral Relations in the Mediterranean. Prospects for Migration Issues (Edward Elgar, 2020), 215. 
municipal level. ${ }^{38}$ Indeed, it is not difficult to understand that one of the distinctive features of soft law - that is, its flexibility - may represent a significant advantage in crisis scenarios.

This said, and even if the recourse to EU informal instruments in time of crises does not come as a surprise, it remains that this trend is far from being unproblematic. The most relevant issues related to a massive recourse to softlaw instruments are represented by: (a) the transparency and legitimacy of the corresponding action - these acts being normally adopted without the democratic control exerted by the European Parliament; (b) the legal certainty of the legal framework they contribute to establish; and, finally, (c) their justiciability or invocation before EU and national tribunals. ${ }^{39}$

Considering that the European Union is normally understood - according to a celebrated formula elaborated by the EU Court of Justice - as a Union 'based on the rule of law, inasmuch as neither its Member States nor its institutions can avoid a review of the question whether the measures adopted by them are in conformity with the basic constitutional charter, the Treaty',40 it becomes evident that an increasing recourse to soft-law instruments should represent a cause of major concern for all $\mathrm{EU}$ actors.

Actually, at the end of 2020, taking stock of some lessons learned during the initial stage of the pandemic, the European Commission has launched a package of initiatives that should pave the way for the establishment of a strong(er) cooperation platform, giving the European Union the proper instruments 'to prevent, prepare for and manage health crises both at the EU and global level: ${ }^{41} \mathrm{~A}$ building block for the establishment of such a platform is represented by the Proposal for a Regulation on serious cross-border threats that would replace Decision 1082/2013/EU. ${ }^{42}$ The proposed regulation introduces a stronger and more comprehensive legal framework for health crisis preparedness and response at EU level and enhances the Union's guidance in the adoption of common measures at EU level to face future cross-border health threats. Particularly relevant is the choice of the instrument, a regulation, which is

38 For a general overview see the contributions to the Special Issue 1/2021 on COVID-19 and Soft Law of the European Journal of Risk Regulation.

39 Oana Stefan, 'COVID-19 soft law: voluminous, effective, legitimate? A research agenda' (2020) 5 European Papers. European Forum, 663; Mariolina Eliantonio, Oana Stefan, 'The elusive legitimacy of EU soft law: an analysis of consultation and participation in the process of adopting COVID-19 soft law in the EU' (2021) 12 European Journal of Risk Regulation, 159 .

40 Case 294/83 Parti écologiste 'Les Verts' ECLI:EU:C:1986:166, para. 23.

41 European Commission, Building a European Health Union: reinforcing the EU's resilience for cross-border health threats, doc. $\operatorname{COM}(2020) 724$ final, 11 November 2020, 2.

42 European Commission, doc. $\operatorname{COM}(2020) 727$ final, 11 November 2020. 
considered by the European Commission 'the most suitable instrument as a key element of the proposal is to establish procedures and structures for cooperation on joint, EU-level work: ${ }^{43}$ No doubt, the adoption of a regulation would represent a choice significantly reinforcing the cooperation in that domain: as it is well-know, regulations are the most powerful binding acts at the disposal of EU institutions, being binding in all their elements and directly applicable in the Member States' municipal orders (Article 288 TFEU). Thanks to those features, regulations are normally used by the EU legislature to harmonise the national legislation of Member States. In this respect, it is at least debatable whether that choice may be considered perfectly consistent with the mandate conferred upon the Union in the context of the protection of human health, this latter being covered, as already mentioned, by a soft competence of the EU, which may only support, coordinate or supplement the actions of the Member States (Article 6 TFEU). ${ }^{44}$

More generally, although relevant, the initiative launched by the European Commission simply ignores the legal implications flowing from the recourse to soft-law instruments to face the pandemic. In the absence of a concrete perspective for a significant reform of the EU Treaties, leading to a more consolidated legal framework for the EU's action in the mentioned areas, it seems to the present author that a general reflection on the proliferation of EU softlaw instruments in times of crisis - and related risks - should be as urgent as it is inevitable.

\section{Zoom in: The Union Civil Protection Mechanism in Times of Pandemic}

One of the most relevant issues related to the implementation of the UCPM in the context of COVID-19 response concerned the lack of availability of medical equipment to be deployed to States in need through the EU cooperation

43 Ibid., 4.

44 Pursuant to Article 2, para 5, TFEU, '[1] egally binding acts of the Union adopted on the basis of provisions of the Treaties pertaining to these areas shall not entail harmonisation of Member States' laws or regulations'. It is interesting to note that the regulation has also been used to revise (not replace!) the UCPM, which is also covered by the EU soft competence. That revision has been finalized in 2021 and it is not discussed here. It suffices to mention that the main point of that reform is represented by a further strengthening of the RescEU capacities. Cfr. Regulation (EU) 2021/836 of 20 May 2021 amending Decision No 1313/2013/EU on a Union Civil Protection Mechanism, oJ L185, 26 May 2021, 1. A consolidated text of Decision 1313/2013 is available at $<$ https://eur-lex.europa.eu/eli/ $\mathrm{dec} / 2013 / 1313 / 2021-01-01>$. 
platform. In particular, during the first stage of the pandemic emergency, Italy - the EU State hardest hit by the coronavirus - was refused ventilators, face masks and medical supplies under the UCPM. ${ }^{45}$ This event was considered as a lack of concrete solidarity among Member States, ${ }^{46}$ further exacerbated by the 'external assistance' offered by some third countries. ${ }^{47}$ Even if figures concerning the assistance provided at the supranational level during the pandemic seem to show a different scenario, ${ }^{48}$ it is true that the assistance took a significant time to get organised. The main problem in this respect was represented by the voluntary nature of the in-kind assistance established under the UCPM. Also relevant was the inadequacy of the existing RescEU capacities to give rise to an effective reaction in the case of Member States' shortages of medical equipment. Against this background, in March 2020, the European Commission adopted an implementing decision to include in the RescEU capacities the stockpiling of medical countermeasures, intensive care medical equipment, and personal protective equipment aimed at combating serious cross-border threats to health. ${ }^{49}$

This development deserves to be stressed for two reasons, at least. First, it confirms that the voluntary essence of the UCPM, even if coherent with the nature of the EU competence in that domain, may represent a major shortcoming of the mechanism itself, particularly in cases where the emergency at stake assumes a general dimension (affecting thus a large majority of EU

45 David M. Herszenhorn et al., 'Europa fails to help Italy in coronavirus fight' (Politico, 5 March 2020) <https://www.politico.eu/article/eu-aims-better-control-corona virus-responses/>.

46 See for instance the parliamentary question submitted by MEP Silvia Sardone to the European Commission on 22 April 2020. European Parliament, Failure to transfer medical supplies to Italy and number of patient sent to other European countries, doc. P-o02428/2020.

47 China offered prompt support to Italy in terms of medical supply and staff via the Emergency Response Coordination Centre: European Commission, Coronavirus: Chinese aid to the EU delivered to Italy, 6 April 2020 <https://ec.europa.eu/commission/presscorner/ detail/en/ip_2o_6oo>.

48 European Council on Foreign Relations, European Solidarity Tracker, <https://ecfr.eu/ special/solidaritytracker/>.

49 Commission Implementing Decision (EU) 2020/414 of 19 March 2020, OJ L82I, 19 March 2020,1 . In order to extend the availability of goods needed to combat the effects of the Covid-19 outbreak, the European Commission has also decided to introduce under the Council Regulation (EC) No 1186/2009 (setting up a supranational system of reliefs from customs duty) a general relief of import duties and exemption of VAT in respect of importations of such goods made from 30 January 2020: Commission Decision (EU) 2020/491 of 3 April 2020, OJ LI103, 3 April 2020, 1. A tentative list of products eligible to be imported duty - vAT free is available at: <https://ec.europa.eu/taxation_customs/system/files/2021 -04/eu_indicative_list_decision_covid19-c202O_491_19_april_2021.pdf $>$. 
Member States). Secondly, as rightly stressed by some scholars, ${ }^{50}$ it shows that the activation of the RescEU reserve, which is based on a closed list of available resources, to be defined by means of implementing decisions adopted by the Commission according to a set of procedures in which the institution work under the supervision of Member States' representatives, ${ }^{51}$ risks being ineffective (or late, at least) in case of unpredicted crisis scenarios. Yet, Article 10 of the UCPM Decision obliges the Commission and Member States to work together to improve cross-sectoral disaster risk management planning at the EU level. Also, Article 12 of that Decision, as amended in 2021, provides that the definition of RescEU capacities by the Commission shall be based inter alia on any existing scenario-building as referred to in Article 10(1), taking into account identified and emerging risks and overall capacities and gaps at Union level, in particular in the areas of aerial forest-firefighting, chemical, biological, radiological and nuclear incidents, emergency medical response, as well as transport and logistics'. As clearly illustrated by the initial response to the COviD-19 pandemic, however, such a machinery, even if consistent with the "soft" nature of the competence exercised by the Union in the field of the civil protection cooperation, could lead to a reappraisal of the scope (as well as the effectiveness) of the RescEU reserve.

50 Mauro Gatti, 'Febbraio. La risposta europea all'emergenza da COVID-19', in Pietro Manzini, Michele Vellano (eds) Unione Europea 2020. I dodici mesi che hanno segnato l'integrazione europea (Wolters Kluwer-CEDAM 2021) $5^{\circ}$.

51 These procedures, known as 'comitology', are set up by Regulation (EU) 182/2011 of 16 February 2011 laying down the rules and general principles concerning mechanisms for control by Member States of the Commission's exercise of implementing powers, OJ L55, 28 February 2011, 13 . 